\title{
Contributors to This Issue
}

James M. Brophy is the Francis H. Squire Professor of History at the University of Delaware. He has written Capitalism, Politics, and Railroads in Prussia, 1830-1870 (1998) and Popular Culture and the Public Sphere in the Rhineland, 1800-1850 (2007) as well as co-edited Perspectives from the Past: Sources in Western Civilization (5th ed., 2012). In addition, he has published numerous essays on nineteenthcentury Germany and Europe. He is currently working on Markets of Knowledge: Publishers and Politics in Central Europe, 1770-1870, a book that examines German publishers as cultural brokers, political actors, and as entrepreneurs of print.

SACE Elder is an Associate Professor of History at Eastern Illinois University. She is the author of Murder Scenes: Normality, Deviance, and Criminal Violence in Weimar Berlin (2010) and is currently working on a book project that examines the anticruelty movement and child abuse in early twentieth-century Germany.

Jonathan Huener is an Associate Professor of History at the University of Vermont (Department of History, University of Vermont, 133 S. Prospect St., Burlington, VT 05401; e-mail: jhuener@uvm.edu). He is author of Auschwitz, Poland, and the Politics of Commemoration, 1945-1979 (Athens: Ohio University Press, 2003), which was awarded the 2004 Orbis Books Prize in Polish Studies from the American Association for the Advancement of Slavic Studies. In addition, he is co-editor, with Francis R. Nicosia, of Medicine and Medical Ethics in Nazi Germany: Origins, Practices, Legacies (New York: Berghahn, 2002), Business and Industry in Nazi Germany (New York: Berghahn, 2004), and The Arts in Nazi Germany: Continuity, Conformity, Change (New York: Berghahn, 2006). He is currently completing a monograph on Polish Catholicism and the Polish Roman Catholic Church in the Reichsgau Wartheland.

Christopher A. Molnar is an Assistant Professor of German and French history at the University of Michigan-Flint. He has published articles on immigration in postwar German history and is currently working on a book manuscript provisionally entitled Nation, Migration, and Cold War: Yugoslavs in Germany, 1945-1995.

Adam T. Rosenbaum is an Assistant Professor of History at Colorado Mesa University (Department of Social and Behavioral Sciences, 1100 North 
Avenue Grand Junction, CO 81501; e-mail: arosenba@coloradomesa.edu). His dissertation, "Timeless, Modern, and German? The Re-Mapping of Bavaria through the Marketing of Tourism, 1800-1939," received the Parker-Schmitt Dissertation Prize from the European History Section of the Southern Historical Association, and the Fritz Stern Dissertation Prize, annually awarded by the Friends of the German Historical Institute in Washington, D.C. He is currently at work on a book manuscript, provisionally titled In the Shadow of the Present: Bavarian Tourism and Grounded Modernity, 1800-1950."

Janek Wasserman is an Assistant Professor of Modern German and Central European History at the University of Alabama. He received his Ph.D. in European History from Washington University in St. Louis. His book, Black Vienna: The Radical Right in the Red City, 1918-1938 will appear with Cornell University Press in June 2014. His research interests are Austrian and European intellectual history, modern Central European history, and the history of economic thought.

Albert Wu is an Assistant Professor in the Department of History at the American University of Paris. 


\section{FORTHCOMING}

\section{Volume 47 \\ Number 2 \\ 2014}

ARticles

FROM THE GRÜNE WIESE TO URBAN SPACE:

BERLIN, EXPANSION AND THE LONGUE DURÉE

Introduction

Shantytowns and Pioneers Beyond the City Walls: Berlin's

Urban Frontier in the Nineteenth Century

Kristin Poling

Urban Sewage and Green Meadows: Berlin's Expansion

to the South, 1870 to 1920

Marion W. Gray

The Nature of Berlin: Green Space and Visions of a New

German Capital, 1900-1945

Barry A. Jackisch

Amnesiopolis: From Mietskaserne to Wohnungsbauserie 70

in East Berlin's Northeast

Eli Rubin

Other Articles

'Censorship Is Official Critique': Contesting the Limits

of Scholarship in the Censorship of the Hallische Jahrbücher

Matthew Bunn

The Search for the 'Other Germany': Refugee Historians from Nazi Germany and the Contested Historical Legacy of the Resistance to Hitler

Marjorie D. Lamberti

BoOK Reviews 


\section{Editorial Policy}

Central European History publishes articles, review articles, book reviews, and conference reports dealing with the history of German-speaking central Europe. The journal solicits manuscripts using all approaches to history and dealing with all historical periods. Because space is limited, articles that have been or soon will be published elsewhere are not accepted. Manuscripts submitted to $\mathrm{CEH}$ should not be under consideration by another journal pending decision of the editor on publication. If it is learned that an article is under submission to another journal while being considered at $\mathrm{CEH}$, consideration will cease immediately. Unsolicited book reviews are not accepted.

\section{Manuscripts and correspondence should be directed to:}

The Editor

Central European History

Case Western Reserve University

Department of History

Mather House Room 209

11201 Euclid Avenue

Cleveland, OH 44106-7107

Email: centraleuropeanhistory@case.edu

The editors prefer that manuscripts be submitted in electronic form as email attachments sent to the journal's address, preferably in Microsoft Word 2003 or later or WordPerfect 12.0 or later; Adobe Acrobat pdf files will also be reviewed. Manuscripts submitted in printed form must be accompanied by a compact disk or diskette with the article in Word, WordPerfect, or pdf. The entire text of all manuscripts, including footnotes and headings, must be prepared in double-spaced typescript with generous margins to allow for copyediting. Footnotes must be numbered consecutively and should be placed in a separate section at the end of the text.

Correspondence concerning book reviews should be sent to:

The Associate Editor

Central European History

Department of History

Amherst College

Amherst, MA 01002

Email: ceh@amherst.edu

Further guidelines for the preparation of manuscripts for publication in Central European History will be sent upon acceptance of materials by the editor. All materials will be edited to conform with The Chicago Manual of Style in matters regarding punctuation, capitalization, and format. The final decision on style remains with the editor. 
